\title{
International Accounting Rate Reform in Telecommunications
}

\author{
Muhammad AbBas Choudhary and Muhammad SAEED
}

INTRODUCTION

Twenty European countries came together in 1865 to form an organisation, the predecessor to the International Telecommunications Union and to arrive at mechanisms and agree upon a methodology of distributing the revenues from the international telegraph service. The current accounting rate system is a modified version of the then developed methodology for the International telegraph. This international settlement regime based on accounting rates has long been under attack by economists, policy-makers in developed countries and international trade organisations. The ITU, the OECD, the FCC and other regulatory bodies are pursuing various initiatives to reform or replace the existing accounting rate system. These regulatory initiatives are aimed at reducing the current pricing distortions embedded in the accounting rate system. In the wake of the WTO agreement, a system of traffic compensation that is not 'cost oriented' is not only unsustainable, it is also in violation of the regulatory principles set out in the WTO reference paper.

The FCC has been at the forefront of the move to decrease accounting rates. In August 1997, the FCC adopted "benchmark" accounting rates for different groups of countries, which it considered more closely related to the actual costs of providing international service between those countries and the US. The benchmark rates range from $\$ 0.15-\$ .23$ per minute, and are far below those currently in practice, particularly for most of the developing countries which are sometimes in excess of $\$ 1.00$ per minute. If implemented, these rates would significantly reduce international calling revenues of these countries. While the FCC obviously has no direct regulatory jurisdiction outside of the US, it has threatened to deny access to the US market to PTOs from other countries that do not reduce their accounting rates to the benchmark levels.

While the future of the existing accounting rate system is being debated in regulatory circles, an increasing proportion of international traffic is bypassing this traditional system of compensation. Facilitated by the global trend towards the liberalisation of telecommunications markets, new technological means for bypassing the accounting rate system are also developing rapidly.

Muhammad Abbas Choudhary is Director, Policy and Research/ITU. Muhammad Saeed is Director Tariff and Interconnection at Pakistan Telecommunications Authority, Islamabad.

Authors' Note: The views presented in this paper are of the authors and not necessarily of Pakistan Telecommunications Authority. 
A recent ITU report 22 identifies a number of technological and service innovations that are undermining the accounting rate system. These innovations or "new modes of operation" include international simple resale, refile and hubbing arrangements and IP telephony. The impact of these new arrangements on the accounting rate system is far-reaching. For example, the ITU report notes that "new modes of operation", including IP telephony, offer major opportunities for diverting traffic from the settlement process.

Recent technological developments, together with the beginnings of gateway arrangements allowing telephone calls to flow between the Internet and the PSTN, opens up a realistic possibility. The carriage of international telephone calls via the Internet ("IP telephony") will soon move from its original more or less prototype or hobbyist status to become a major "mode of operation" for carrying commercial traffic. It seems so far that this may happen entirely outside the conventional regulatory framework; it is certainly happening outside the traditional settlement systems.

The pressures that IP telephony and other alternative network services are placing on the accounting rates system are recognised by many industry observers as accelerating the move towards open telecommunications markets and 'cost-oriented' settlement rates.

\section{UNDERSTANDING ACCOUNTING RATE SYSTEM}

An international accounting rate is the basis for the price charged by an international carrier to terminate an international switched telephone call that originates in another country. The price is negotiated between the originating international carrier and the terminating international carrier. Normally, the originating carrier owes the terminating carrier half the accounting rate for each minute of service. This is referred to as the settlement rate. It is used to determine the payments between international carriers to deliver international calls.

International call charges are one of the most important elements of a tariff structure because international service is one of the fastest growing and, currently, most profitable part of the telecommunication sector. Thus international service has traditionally been used to cross-subsidise national network development. The case of Hungary provides a good example. International services generate around one-third of the total revenue of the Hungarian Telephone Company and an even higher percentage of profits. Furthermore, a substantial part of the income from international services comes in the form of hard currency (e.g. incoming settlement payments, payments from foreign companies and residents) which can be used more easily in some developing countries to fund equipment purchases from abroad.

Revenue sharing formula for accounting rate settlement has a twofold pricing methodology. The first one is a retail payment by the international subscriber to the PTO that originates the call. It may also be called as the collection charges. It is 
generally charged in local currency units. A second price, that is bargained between the original operator and the operator terminating the call for each minute of traffic, on a revenue sharing formula, is labeled as the accounting rate. The settlement is usually made in international currency units such as US Dollars or Special Drawing Rights (SDR: a basket of currencies consisting of Dollars, Sterling, Deutsche Mark, Yen and French Franks). If an imbalance exists in the volume of the incoming and outgoing calls, then the originating operator that generates more outgoing traffic compensates the terminating operator with a net settlement payment. Usually, the settlement rate is 50 percent, as the cost of an international call is shared equally between the originating and terminating international carriers. The accounting rate can be explained with the following Figure 1 below.

\section{What is an accounting rate?}

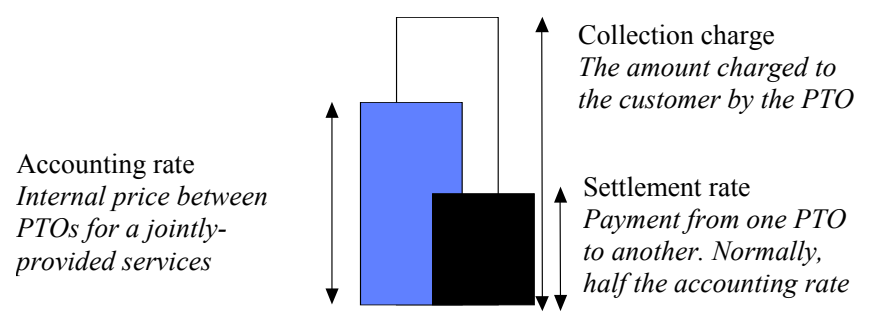

Fig. 1. Accounting Rates, Collection Charge and Settlement Rates.

\section{CURRENT TELECOM ENVIRONMENT}

Telecom is a big business that also acts as an accelerator to the economic activity. The international telecom traffic, which is well over 100 billion minutes, is expected to reach 143 billion minutes by the year 2001. The international telecom traffic trend is projected in Figure 2. It is also notable that about 75 percent of the international outgoing international traffic is being generated in 23 economically developed countries while the rest of the world accounts for only 25 percent of the international outgoing traffic. The amount of international outgoing traffic in the top 20 developing as well as top 20 developed countries is presented in Table 1 and 2 respectively.

It is also important to understand the dynamics of telecom traffic. Figure 3 a and b depict global shares of international telecom traffic in 1983 and 1997 respectively. Europe that used to be the leader with 68 percent share dropped to 43 percent in 1997. America almost doubled its share from 16.8 in 1983 to 32.5 percent. Asia-Pacific also almost doubled its share from 9.7 percent in 1983 to 18.5 percent in 1997. The Latin American countries and Africa remained almost at the same level. These numbers are not only the indicators of international traffic dynamics but also very good indicators of the concentration of economic activity on the globe. 
Table 1

Top 20 Developing Country Public Telecommunication Operators (Ranked in Terms of Minutes of Outgoing International Traffic, 1997)

\begin{tabular}{|c|c|c|c|c|c|c|c|}
\hline Rank & PTO (Economy) & $\begin{array}{l}\text { Financial } \\
\text { Year End }\end{array}$ & $\begin{array}{c}\text { Minutes of } \\
\text { International } \\
\text { Telecommuni- } \\
\text { cation Traffic, } \\
1997(000 \mathrm{~s})\end{array}$ & $\begin{array}{l}\% \text { Change } \\
1996-1997\end{array}$ & $\begin{array}{c}\text { Revenue from } \\
\text { International } \\
\text { Services } 1997 \\
\text { (US\$m) }\end{array}$ & $\begin{array}{c}\% \\
\text { Change, } \\
1996- \\
1997 \\
\end{array}$ & $\begin{array}{c}\text { International } \\
\text { Revenue as \% } \\
\text { of Total } \\
\text { Telecommuni- } \\
\text { cation } \\
\text { Revenue } \\
\end{array}$ \\
\hline 1 & $\begin{array}{l}\text { Hong Kong Telecom International } \\
\text { (Hong Kong-China) }\end{array}$ & 1 April & $1,718.0$ & -1.2 & $2,194.9$ & -2.5 & 48.5 \\
\hline 2 & DGT (China) & 31 Dec. & $1,632.0$ & 13.9 & $2,107.4$ & 26.3 & 12.3 \\
\hline 3 & Telmex (Mexico) & 31 Dec. & $1,009.0$ & -5.8 & $1,446.3$ & -23.6 & 18.9 \\
\hline 4 & MOPTT (Saudi Arabia) & 31 Dec. & 801.3 & 37.1 & $1,174.9$ & 11.7 & 50.3 \\
\hline 5 & SingTel (Singapore) & 1 April & 753.0 & 21.6 & $1,377.8$ & 2.6 & 46.7 \\
\hline 6 & Chungwa Telecom (Taiwan-China) & 30 June & 743.1 & 14.5 & 797.1 & -14.3 & 15.7 \\
\hline 7 & Etisalat (United Arab Emirates) & 31 Dec. & 738.0 & 25.2 & 472.9 & -9.1 & 42.0 \\
\hline 8 & KT (Korea (Rep. of)) & 31 Dec. & 610.0 & 17.3 & $1,227.6$ & 8.6 & 14.4 \\
\hline 9 & TM (Malaysia) & $31 \mathrm{Dec}$. & 589.0 & 3.2 & 497.6 & -3.5 & 19.5 \\
\hline 10 & Turk Telekom (Turkey) & 31 Dec. & 557.5 & 17.8 & 460.9 & 8.1 & 12.8 \\
\hline 11 & TP (Poland) & 31 Dec. & 529.4 & 21.1 & 670.9 & 6.4 & 25.2 \\
\hline 12 & Utel (Ukraine) & 31 Dec. & 487.0 & 461.1 & 172.3 & 3.5 & - \\
\hline 13 & EMBRATEL (Brazil) & $31 \mathrm{Dec}$. & 477.0 & 24.6 & 399.7 & 9.3 & 19.9 \\
\hline 14 & VSNL (India) & 1 April & 422.0 & 9.6 & $1,599.7$ & 9.1 & 90.8 \\
\hline 15 & Telkom (South Africa) & 1 April & 368.8 & 4.5 & 652.9 & 0.6 & 14.9 \\
\hline 16 & SPT Telecom (Czech Republic) & 31 Dec. & 306.1 & 5.7 & 240.6 & -27.5 & 19.1 \\
\hline 17 & Bezeq (Israel) & 31 Dec. & 300.0 & -6.3 & 428.8 & -45.3 & 16.9 \\
\hline 18 & Indosat (Indonesia) & 31 Dec. & 298.1 & 20.1 & 443.1 & -7.1 & 88.6 \\
\hline 19 & Rostelecom (Russia) & 31 Dec. & 288.5 & 23.3 & 279.4 & -64.5 & 17.5 \\
\hline \multirow[t]{2}{*}{20} & HTC (Hungary) & 31 Dec. & 287.1 & 7.4 & 191.4 & 80.7 & 14.1 \\
\hline & Average/Total & & $12,914.8$ & 14.8 & $16,836.2$ & 3.7 & 22.7 \\
\hline
\end{tabular}

Source: ITU PTO Database.

Table 2

Top 20 Developed Country Public Telecommunication Operators (Ranked in Terms of Minutes of Outgoing International Traffic, 1997)

\begin{tabular}{|c|c|c|c|c|c|c|c|}
\hline Rank & PTO (Economy) & $\begin{array}{l}\text { Financial } \\
\text { Year End }\end{array}$ & $\begin{array}{c}\text { Minutes of } \\
\text { International } \\
\text { Telecommuni- } \\
\text { cation Traffic, } \\
1997(000 \mathrm{~s})\end{array}$ & $\begin{array}{l}\% \text { Change } \\
1996-1997\end{array}$ & $\begin{array}{c}\begin{array}{c}\text { Revenue } \\
\text { from }\end{array} \\
\text { International } \\
\text { Services } 1997 \\
\text { (US\$m) }\end{array}$ & $\begin{array}{l}\text { \% Change, } \\
1996-1997\end{array}$ & $\begin{array}{c}\text { International } \\
\text { Revenue as \% } \\
\text { of Total } \\
\text { Telecommuni- } \\
\text { cation } \\
\text { Revenue } \\
\end{array}$ \\
\hline 1 & AT\&T (United States) & 31 Dec. & 10,331 & 8.2 & 5,786 & 0.2 & 11.3 \\
\hline 2 & MCI WorldCom (United States) & 31 Dec. & 2,307 & 17.6 & 4,743 & 21.1 & 17.9 \\
\hline 3 & Deutsche Telekom (Germany) & 31 Dec. & 4,813 & 1.1 & 3,806 & -7.6 & 9.8 \\
\hline 4 & France Telecom (France) & 31 Dec. & 3,100 & 4.4 & 2,165 & -25.1 & 8.1 \\
\hline 5 & Sprint (United States) & 31 Dec. & 2,759 & 0.5 & 1,478 & -1.0 & 9.9 \\
\hline 6 & BT (United Kingdom) & 1 April & 2,710 & 4.5 & 2,542 & -9.9 & 9.9 \\
\hline 7 & Telecom Italia (Italy) & 31 Dec. & 2,209 & 8.9 & 1,520 & -6.4 & 8.7 \\
\hline 8 & Swisscom (Switzerland) & 31 Dec. & 1,957 & 6.6 & 965 & -9.9 & 14.2 \\
\hline 9 & Telefonica (Spain) & 31 Dec. & 1,566 & 31.7 & 824 & -15.2 & 5.1 \\
\hline 10 & KPN (Netherlands) & 31 Dec. & 1,535 & 0.1 & 1,072 & -17.4 & 13.5 \\
\hline 11 & Belgacom (Belgium) & 31 Dec. & 1,340 & 14.9 & 565 & -19.1 & 13.3 \\
\hline 12 & Teleglobe (Canada) & 31 Dec. & 1,124 & 22.9 & 779 & 2.4 & 54.2 \\
\hline 13 & KDD (Japan) & 1 April & 1,105 & 0.2 & 2,079 & -14.5 & 68.9 \\
\hline 14 & PTA (Austria) & 31 Dec. & 996 & 5.1 & 492 & -11.8 & 13.2 \\
\hline 15 & C\&W Comms (United Kingdom) & 1 April & 971 & 27.3 & 381 & 14.8 & 10.2 \\
\hline 16 & Telia (Sweden) & 31 Dec. & 747 & 5.8 & 259 & -27.0 & 4.3 \\
\hline 17 & Pacific Gateway (United States) & - & 720 & - & 173 & - & - \\
\hline 18 & Telstra (Australia) & 30 June & 700 & 0.3 & 996 & -4.9 & 8.4 \\
\hline 19 & Telecom Eireann (Ireland) & 1 April & 635 & 9.5 & 606 & 8.3 & 29.5 \\
\hline \multirow[t]{2}{*}{20} & OTE (Greece) & 31 Dec. & 597 & 15.2 & 548 & -2.9 & 16.7 \\
\hline & Average/Total & & 47,323 & 8.6 & 31,779 & -5.1 & 11.1 \\
\hline
\end{tabular}


Figure 2

Figure $3 a \& 3 b$

It is also a critical consideration that the market structure of the telecom sector is changing rapidly. During 1990 only 4 countries had permitted competition in international telephony, which increased to 14 countries in 1995 and further increased to 39 in 1998. It is projected as is shown in Figure 4 that by the year 2005, 85 percent of international telephone traffic will be carried out under competitive conditions. It is also important to understand that more than 150 countries have introduced new telecommunications regulation or modified the existing regulation during the 19901998 period. The work at this front has given rise to the creation of 84 separate regulators as of August 1999. The growth of independent telecom regulation organisations and its distribution in various regions is presented in Figure 5. 
Figure 4

Figure 5

The influence of WTO Agreement on Basic Telecommunications, which is signed by some 69 countries and of which Pakistan is also a signatory, is likely to have profound impact on this whole issue.

It is indeed a serious situation and can have far reaching impact particularly on the economies of the developing countries.

\section{DISCUSSION ON THE ISSUES}

During the period between 1993 and 1998, a total of around USD 40 billion passed from developed countries to the developing world through the workings of 
the accounting rate system. The United States alone contributed more than 25 billion to this net transfer. Understandably, developing countries are fearful about what will happen to this source of funds as a result of the changes to the international telecommunications environment. Many developing countries are vulnerable to sudden changes, particularly small island states and others, which derive a large percentage of their total telecommunication revenues from international traffic. Different scenarios for reform of the accounting rate system, including FCC benchmarks, the Group on Accounting Rate Reform, termination rates, staged reductions and a move towards sender-keeps-all are being debated at different regional and international forums. Whichever scenario comes to pass, it is likely that the current volume of cross-border financial transfers, particularly from developed to developing countries, will diminish in size and significance.

Developing countries face a dilemma: do they continue to keep wholesale and retail prices for international traffic high, in order to cross-subsidise access networks, or should they cut prices in order to prevent traffic streams shifting to the Internet? The preliminary 1998 traffic statistics show an appreciable downturn in the rate of growth (falling below 10 percent for the first time in several decades) and actual decline in outgoing traffic in the case of some economies, such as Hong Kong-China. While the downturn in the Asia-Pacific region may be partly a result of the Asian financial crisis, a further explanation is almost certainly due to the loss of accounting rate traffic, especially fax, to the Internet.

The problems of the countries that have difficulty with the current accounting rate system is understandable but any unilateral decision as depicted in the FCC's adoption of International Settlement Rate Benchmarks in August 1997 will have adverse and unhealthy effect on the world telecom sector. The decision should be beneficial to 75 percent of the world. This is a reality that the benchmark rates, which are favourable to only one nation, are being imposed on the rest of the world. This may give an immediate relief to the nations on the other side of the argument but is definitely unhealthy for the world telecom industry. The point is the current ARS are not unilateral but a result of business bargain between the operators of various nations. If some nations try to decrease their settlement bills by getting shelter under national regulatory authorities or adopting technical or administrative bypass methodologies, this should be treated as an unfair trade practice and the WTO shall take a notice of this.

Telecom is probably the only sector where the USA has to make settlement payment because of the deficit projected by the FCC. However there are numerous other areas where other nations are in greater deficit and the balance is in favour of the United States.

The FCC decision will affect large parts of the world and can have far reaching effect not only on the telecom sector but on the global economy, because the telecom services as an ingredient in the economic system will 
become costly. The main losers will be the resource starved underdeveloped countries. The loss of major revenue coming from settlement payments will necessitate the reduction on the sectoral development expenditures and network expansions will come to a stand still. The net cost to the nations that will reduce their settlement payment bill still will be higher because they are the major exporter of equipment and system development and integration services. This would affect the development of world telecom industry and slow down the pace of growth rate of the industry.

The telecom operators from industrialised countries also stand to benefit from public network expansion in developing countries, which allows more customers to make more international calls. If investment in these networks is curtailed, congestion and other problems may occur, which in turn means extra cost to the calloriginating operators. It should be understood that the revenues due to present imbalances in Accounting Rate Settlement go back to the developed world for the purchase of equipment, expert help and other similar costs.

Nobody could deny the virtues of global free market, liberalisation and competition but for equitable dividends to all the partners. We fully appreciate the spirit of international co-operation. Pakistan is already signatory to WTO and we are contemplating to join the IT Convention. We are the proponents of technology for development and opportunities for all. The free market economy principles suggest that competition does not mean exploitation of the weak and resourcesless nations. The market economy may only boom with more and more nations capable of network expansion and growth.

\section{PAKISTAN AND ACCOUNTING SETTLEMENT RATES}

Pakistan is among the top 10 net settlement surplus countries. As shown in Table 3 Pakistan is at number four with estimated net settlement over US $\$ 500$ million in 1997. As such reducing the settlement rate from 90 cents to 23 cents means eroding the revenues to a quarter of the current level despite the growth in international traffic. According to the ruling, Pakistan will have to implement a benchmark settlement rate of US $\$ 0.23$ /minute by January 01,2002 with the US carriers. PTCL had signed agreements with US carriers for a settlement rate of US $\$ 0.90$ per minute until June 1998. This implies that post June 1998, PTCL will have to reduce its accounting rate by approximately 28 percent per annum in order to meet the deadline. Therefore, we believe that despite a good 16.4 percent per annum growth in inbound IDD minutes and an expected 9.0 percent per annum devaluation of the Pakistan rupee against the US dollar, inbound IDD revenues will show a declining trend to 2002, negatively affecting overall profitability. 
Table 3

Top 10 Net Settlement Surplus Countries, 1997

(As Measured by Estimated Net Settlements from the Rest of the World, in US\$ Million, 1997)

\begin{tabular}{|c|c|c|c|c|c|c|}
\hline Countries & $\begin{array}{l}\text { Outgoing } \\
\text { Traffic } 1997 \\
\text { (Million } \\
\text { Minutes) }\end{array}$ & $\begin{array}{c}\text { Incoming } \\
\text { Traffic } 1997 \\
\text { (Million } \\
\text { Minutes) } \\
\end{array}$ & $\begin{array}{l}\text { Imbalance } \\
\text { (Outgoing } \\
\text { Minus } \\
\text { Incoming) } \\
\end{array}$ & $\begin{array}{c}\text { Imbalance } \% \text { of } \\
\text { Total Traffic }\end{array}$ & $\begin{array}{l}\text { US Settlement } \\
\text { Rate, } 1997 \\
\text { (US Cents per } \\
\text { Minute) } \\
\end{array}$ & $\begin{array}{c}\text { Estimated } \\
\text { Net } \\
\text { Settlement, } \\
1997 \\
\text { (US\$m) }\end{array}$ \\
\hline China & $1,631.8$ & $2,400.0$ & -768.2 & $-19.1 \%$ & 84.5 & 650 \\
\hline India & 420.5 & $1,256.0$ & -835.5 & $-49.8 \%$ & 71.0 & 600 \\
\hline Mexico & $1,213.6$ & $2,819.3$ & $-1,605.7$ & $-39.8 \%$ & 35.0 & 600 \\
\hline Pakistan & 76.9 & 565.3 & -488.4 & $-76.1 \%$ & 100.0 & 500 \\
\hline Viet Nam & 55.8 & 310.0 & -254.2 & $-69.5 \%$ & 100.0 & 260 \\
\hline Philippines & 249.5 & 709.0 & -459.5 & $-47.9 \%$ & 50.0 & 230 \\
\hline Lebanon & 60.0 & 240.0 & -180.0 & $-60.0 \%$ & 87.5 & 160 \\
\hline Colombia & 158.2 & 439.0 & -280.8 & $-47.0 \%$ & 50.0 & 140 \\
\hline Jamaica & 51.6 & 269.3 & -217.7 & $-67.8 \%$ & 62.5 & 140 \\
\hline Brazil & 476.9 & 776.7 & -299.8 & $-23.9 \%$ & 42.5 & 130 \\
\hline Top 10, Total/Average & $4,394.7$ & $9,784.6$ & $-5,389.9$ & $-38.0 \%$ & 62.0 & 3,410 \\
\hline $\begin{array}{l}\text { All Net Surplus } \\
\text { Countries, } \\
\text { Total/Average }\end{array}$ & $32,234.4$ & $44,248.9$ & $-12,014.5$ & $-15.7 \%$ & 36.2 & 6,200 \\
\hline
\end{tabular}

Source: ITU/TeleGeography Inc. "Direction of Traffic Database" FCC.

Note: Figures shown in italics are estimates. All other figures are as reported by the countries concerned. For Jamaica, which does not report bilateral traffic flows, derived statistics for incoming and outgoing traffic for the United States and the United Kingdom, its two major traffic routes, are used.

\section{THE FCC BENCHMARKS}

One of the most radical changes to hit the telecom industry came from the U.S. Government in August 1997. The Federal Communications Commissionwithout negotiating with any other countries-decided to slash the so-called "settlement" fees that U.S. carriers pay foreign companies to complete calls from the U.S. These fees had been set under an international settlement system to compensate countries for handling each other's traffic-and for any imbalance in the volume. For instance, in 1997 U.S. customers spent 495 million minutes on calls to Brazil, but Brazilians made only 159 million minutes' worth of calls to the U.S. To pay for the deficit of 336 million minutes, U.S. carriers sent Brazil a cool \$154.7 million.

On August 07, 1997 the Federal Communication Commission of (FCC) of USA adopted a Report and Order that will significantly reduce the cost of international long distance telephone service by setting new lower benchmarks on international settlement rates. It is contemplated that it will further the development of an open, competitive market for international services. This order, which takes effect on January 01, 1998, will over time reduce settlement rates, thereby sharply cutting U.S settlement payments to foreign carriers. These benchmarks are upper bounds, essentially based on the average "Tariffed Component Prices (TCP)" for each income group. TCPs were calculated using published tariffs for specific network components (international leased line rates and domestic carriage) and ITU data on international gateway costs. Individual 
TCPs vary significantly from country to country. The FCC, in its December 1996 statement, indicated it believes TCPs are well above cost and that international interconnect bases on true cost would be US\$0.06-0.09/minute in most cases. FCC has classified the world into four categories. See Table 4.

Table 4

FCC Benchmarks

\begin{tabular}{llcc}
\hline & $\begin{array}{c}\text { Settlement Rate } \\
\text { Category }\end{array}$ & $\begin{array}{c}\text { Effective } \\
\text { Date }\end{array}$ & $\begin{array}{c}\text { Period } \\
\text { Allowed }\end{array}$ \\
\hline Upper Income & 0.154 per min & Jan 1999 & 1 year \\
Upper Middle & 0.191 & Jan 2000 & 2 years \\
Lower Middle & 0.191 & Jan 2001 & 3 years \\
Lower Income & 0.234 & Jan 2002 & 4 years \\
\hline
\end{tabular}

FCC has allowed five years for those countries whose teledensity is less than 1 percent.

Note that the FCC does not directly set accounting rates. These are determined as a result of bilateral negotiations between carriers. The FCC does, however, have the power to order US carriers to stop paying accounting rates in circumstances where it believes the level of rates to be unreasonable. It used this power in 1996 when there was a dispute between AT\&T and Telintar in Argentina over the level of accounting rates, even though in that case Telintar had reached separate agreements with MCI and Sprint. Also note the FCC's recent tough stance in siding with the US carriers against Telemex.

While some of the rates in the FCC's so-called Benchmarks Order took effect on Jan 01 and others go into effect as late as 2002, the reductions already are having a big impact. Settlement fees often made up half the price of international calls, and the FCC's benchmarks are, in extreme cases, less than example, the $\$ 2.83$ per minute U.S. phone companies now pay to send calls into Afghanistan will be cut to 23 cents in 2002 .

Other countries were upset at the FCC's decision. Its independent move was the opposite of how things used to be done. For the past 134 years, since the telegraph era, countries have held painstaking bilateral negotiations to set what they pay for accepting incoming communications. After the move, a consortium of Latin American countries filed suit in the U.S. against the FCC, arguing it was dictating public policy to other countries. Countries also are turning to the International Telecommunication Union, the Geneva-based body responsible for the settlement rate system, hoping it can negotiate a new multilateral approach. So far, the FCC has won every dispute.

\section{CALL BACK AND OTHER TURNAROUND INNOVATIONS}

The real change goes far beyond cutting settlement payments. As global competition emerges, the whole notion of formal settlement fee is becoming 
obsolete. What's emerging instead is a vibrant free market where dozens of competing companies negotiate directly with one another to link their phone systems, sometimes at no charge. Thanks to deregulation, 48 percent of international phone traffic now is completed for less than the benchmarks required by the FCC. When there is a competition on both ends of the line, rates come down to the public.

To understand why the old international phone system is headed for extinction, rewind to the early 1990s, when the seeds of the revolution were sown. That's when opportunistic newcomers like IDT and Telegroup Inc. started offering inexpensive "callback services to customers outside the U.S. Callback took advantage of the fact that, because of competition in the U.S., it was far cheaper to call abroad from the U.S. than the other way around. The mechanism was dead simple: When John Smith in Tokyo wanted to make a call to New York, he dialed a dedicated number in the U.S., waited a ring or two, and hung up. A computer would then call back, and Smith would hear a U.S. dial tone on the line. Then he could call anywhere in the world and pay U.S. prices. That could have been 36 cents per minute compared to Japanese rates that were up to 10 times higher. As a result, the old system began to crumble.

The second big shock is now just beginning: phone calls over the Internet. From its roots in 1993 as a quick-and-dirty way to talk for free from one PC to another, Internet telephony is becoming an inexpensive alternative to traditional calling (Figure 6). Now, by using gateways that connect conventional phone systems to the Net, carriers can send calls from any phone to another-using the Net as the link across continents or oceans. Bear, Stearns \& Co. analyst Robert Fagin estimates 1.2 billion minutes of international voice traffic will be sent over the Net in 1999, slightly more than 1 percent of the total. As quality improves, that could climb to nearly 7 percent of the market in 2002, or 10 billion minutes, making net telephony a $\$ 968$ million business. 
The leader of the pack in Internet telephony today is startup Net2Phone. The former subsidiary of IDT charges 42 percent less than AT\&T, on average, to make international calls: A minute to France costs customers just 9, against 22 for AT\&T. Others in the field include deltathree.com, a subsidiary of RSL. Communications, and iBasis Inc., a Burlington (Mass.) startup. "It's amazing to see the biggest companies in the world brought to their knees by little American entrepreneurs," says analyst Judy Reed Smith of the research firm Atlantic-ACM.

Where does all of this leave the international telephone system? The glory days are over. The settlement process that for decades subsidised the construction of phone networks around the world is doomed. The advance of technology means that it will be impossible for countries to prop up fees and squeeze strangers in a strange land. Whatever the new system looks like, the fees for completing phone calls across borders inevitably are heading down toward their actual cost.

\section{ITU STUDIES}

The FCC Benchmark Order, the EU Directives, and a strong desire on the part of Administrations in developing countries to determine their costs have been stimuli to the debates in ITU and other regional forums. In March 1998, ITU held a World Telecommunication Policy Forum. As a result of this, a Focus Group was created with a mandate to develop proposals for "transitional arrangements towards cost orientation beyond 1998, including ranges of indicative target rates". The Focus Group has completed its work in November 1998 and its proposal was accepted. They should be formally adopted as part of ITU-T Recommendations D.140 before the end of 1999.

The "indicative target rates" proposed by the Focus Group are different from the Benchmarks put forward by FCC, which are tabulated. See Table 5.

Table 5

ITU Suggested Settlement Rates

\begin{tabular}{lccccrr}
\hline $\begin{array}{l}\text { Teledensity } \\
\mathrm{T}<1\end{array}$ & $1<\mathrm{T}<5$ & $5<\mathrm{T}<10$ & $10<\mathrm{T}<20$ & $20<\mathrm{T}<35$ & $35<\mathrm{T}<50$ & $\mathrm{~T}>50$ \\
\hline $0.327 \mathrm{SDR}$ & $0.251 \mathrm{SDR}$ & $0.21 \mathrm{SDR}$ & $0.162 \mathrm{SDR}$ & $0.118 \mathrm{SDR}$ & $0.088 \mathrm{SDR}$ & $0.043 \mathrm{SDR}$ \\
$(0.443 \mathrm{US} \$)$ & $(0.34 \mathrm{US} \$)$ & $(0.285 \mathrm{US} \$)$ & $(0.22 \mathrm{US} \$)$ & $(0.16 \mathrm{US} \$)$ & $(0.119 \mathrm{US} \$)$ & $(0.058 \mathrm{US} \$)$ \\
\hline
\end{tabular}

The ranges proposed by ITU Study Group are superior to FCC Benchmarks in a number of ways as listed below:

- A deeper understanding of the fundamental cost differences between countries/territories, which are closely related to the development of their telecommunication networks, and therefore, target rates which are different for each category; 
- An acknowledgement that some countries, by virtue of their dependence on net settlement payments, will need a longer period to adjust towards costorientation;

- The focus for the first time on the issue of transit shares with concrete proposals which, if implemented, will bring immediate and direct benefits for developing countries, especially the Least Developed;

- The identification of problems experienced by high cost, small island states and by the Least Developed Countries, which have been demonstrated especially in the work carried out by the ITU Asia-Pacific Regional Office in the Pacific Islands, and concrete proposals to take account of their specific concerns; and

- A comprehensive analysis covering 224 countries/territories going beyond the limited studies covering a few countries/territories as in the case of the FCC study and the country case studies.

\section{Comparison of ITU Rates and FCC Benchmarks}

Figure 7 presents the impact on international settlement payments for 9 selected countries using FCC benchmarks and ITU recommended settlement rates. It is evident that generally ITU suggested settlement rates are relatively better in terms of settlement payment for the selected countries. Although it is a convention that ITU recommendations are highly regarded by the member nations, however, it is imperative that the economically developing nations shall argue their case in ITU and come up with a more equitable and acceptable formula. 


\section{Accounting Rates and Economic Development}

The real reason for all the vitriol is money, of course, lots of money. Because industrialised countries tend to initiate more calls than they receive, the settlement system resulted in a net transfer of billions of dollars from wealthier to poorer nations. Since 1985 , U.S. carriers have paid out some $\$ 43$ billion in settlement fees, including $\$ 1.2$ billion to China, $\$ 1.3$ billion to India, and a stunning $\$ 7.6$ billion to Mexico, according to the FCC. Now, for the first time, these payments are steadily declining. Payments by U.S. carriers reached a peak of $\$ 5.8$ billion in 1996 and fell to an estimated $\$ 4.4$ billion in 1998. U.S. payments likely will drop below $\$ 4$ billion this year. That has put a squeeze on some developing countries. For many, telephone fees are the most or second most important source of hard currency. In 1995, for example, settlement fees accounted for 100 percent of the foreign currency Cameroon received. And they have been a key means for countries to subsidise the construction and operation of their phone networks. India's international phone monopoly, VSNL, gets 37 percent of its $\$ 1.6$ billion in revenues from settlements. Because of the decline in such fees, Sri Lanka Telecom Ltd. has had to double the price of three-minute local phone call. The loss of revenues could crimp economic development, too: For every phone line added in a poor country, its gross domestic product rises by $\$ 2,000$, according to a 1997 study by consulting firm McKinsey and Co.

\section{RECOMMENDATIONS}

- PTCL may be able to convince carriers from "friendly" countries, particularly those from the Middle East, to increase the transition period. Saudi Arabia and the United Arab Emirates (UAE) are two of the top four countries, which generate the most incoming minutes into Pakistan. In FY9697, incoming traffic from these countries was 27 percent of the total incoming minutes. The combined in/out ratio for these countries was 5.3 against an overall ratio of 6.35 in 1997.

- PTCL realises that phased tariff rationalisation is one of the solutions to this problem in the long run. Moreover, PTCL can also try to enter into a relatively longer-term settlement rate reduction schedule as compared to the FCC benchmarks in order to spread the effect of the reduction in settlement rates to slightly beyond January 01, 2002.

- It appears that astute countries should be able to obtain some relief from two sources. First, they may be able to "grandfather" any long-term agreements in place early enough. VSNL recently took this strategy, having concluded a four-year deal, only to have the DoT revoke the accord on grounds that it would negotiate settlement rates itself on an annual basis. On an intermediate term basis, telcos such as PTCL may be able to secure lower reduction in 
accounting rates.

- We should re-emphasise on the factor of developing economies. The favourable settlement imbalance is used to reduce imbalance in development that will be used to expand the networks, which in turn provides impetus to the sale of infrastructure and equipment in the developed world.

- Regional groups can be formed to jointly confront the benchmark implementation and call back and re-file strategies. It is worth noticing that 23 African nations have formed the "African operators Association" in a bid to protect revenues. This association would refuse to deal with established US carriers at benchmark settlement rates. Instead the group claims to have found three smaller US carriers that will provide routing for these countries.

- Steps may be taken to establish POPs (points of presence) by establishing Pakistani long distance companies in those countries wherefrom big volumes of Pakistan bound traffic is originated. It will generate more traffic for the country and also safeguard the national carrier from turnaround and bypass losses. Based on the preliminary analysis it seems that creation of such POPs is more than an economically viable proposition.

- More attention is required towards expansion of data services, which are considered to surpass the voice traffic in near future.

- Among other alternatives, we propose the establishment of a Universal Service Fund on Global Basis under the auspices of ITU. The affected countries shall be supported out of this fund based on comparative decline in their revenues. Similarly concrete and joint policies may also be framed to deal the issues like resale, callback, re-file, and IP Telephony.

- We should join studies in SG III of ITU. 


\section{Comments}

The paper is very interesting and well timed. It examines the issue of Accounting Rate Settlement and its potential effects on our Communication Sector. The old mechanism of distributing the revenues from international communication is now threatened by the decision of Federal Communication Commission (FCC). It is argued that the "benchmarks" set by FCC are biased against developing countries as they will lose the revenues by incoming international communication. So some strategy is needed to cope with this situation.

The paper is well written. The arguments are supported by most recently available data. However, there are some points which need a careful analysis.

First, the authors assume that a decrease in the rates of international communication will decrease the revenues of developing countries because these countries are net receivers of international calls. Infact, the net result is determined by the elasticity of demand. If this elasticity is greater than unity then the revenues of developing countries may increase.

Second, the decrease in rates is in favour of the domestic users. Lower rates will help the domestic producers and exporters to interact more frequently with international community. This will more than offset the losses due to cheap incoming calls.

Third, our communication sector will be forced to adopt the up to date equipments and new marketing techniques.

However, I fully support the authors view that the transition should be smooth. The time frame should be set after due consideration of adaptive capacity of the domestic communication sector.

Finally, a minor point regarding abbreviations. The authors have made an extensive use of abbreviations assuming that the readers are familiar with these. This creates problem in reading the paper and one finds it very difficult what these abbreviations stand for. It would have been better if the authors had attached a list of abbreviations used in the paper.

Fazal Husain

Pakistan Institute of Development Economics, Islamabad. 


\section{Comments}

The study is focused on a very important sector of Pakistan's economy i.e., Growth of Livestock Production: An Analysis.

The paper reviews the growth performance of Pakistan's livestock sub-sector from 1970-71 to 1997-98 (28 Years). The authors have used Total Factor Productivity (TFP) analysis for explaining the growth process in terms of factor inputs and technological breakthrough.

I have some observations on using TFP. As an index for measuring sustainability it does have some drawbacks:

- Data requirements are quite demanding. Detailed data for a number of years are required to form a significant trend that can be very expensive to obtain.

- Some of the computational procedures are quite demanding and it is not clear which index from the number of possible indexes i.e., Laspeyres, Paasche, Fisher, and Divisia one should choose.

- The index number problem would still remain when considering the prices to be used as weights, they must reflect their long-term economic value which is difficult to calculate (Iynam and Herdt).

- It is not obvious that one can obtain the correct data or even define the data correctly.

- It is difficult to identify turning points in the TFP index when projected into future.

Partial Productivity Analysis measures the ratio of total output to a single input. Partial Productivity measures can be a good performance measure input (labour/Feed for example) is the dominant input in production and the input mix of the other input do not change over time.

In brief, this study is a significant contribution to the literature, which provides the bases for a development policy. However, it could be more useful by including the following points.

What are the overall conclusions? Give more in depth analysis at your findings. You need to do more analysis and interpretation of results, not just description. The conclusion needs expansion to include implication.

I complement the authors for attempting a paper on a subject, which is very important for policy formulation.

This paper is a good attempt and I hope that next time the authors would come up with its better and complete version.

Pakistan Agricultural Research Council (PARC),

Muhammad Abdul Quddus Islamabad. 